\title{
Inhibition of dengue NS2B-NS3 protease and viral replication in Vero cells by recombinant retrocyclin-1
}

\author{
Hussin A Rothan ${ }^{1 *}$, Heh Choon Han², Thamil Selvee Ramasamy', Shatrah Othman ${ }^{1}$, Noorsaadah Abd Rahman ${ }^{3}$ \\ and Rohana Yusof ${ }^{1}$
}

\begin{abstract}
Background: Global resurgence of dengue virus infections in many of the tropical and subtropical countries is a major concern. Therefore, there is an urgent need for the development of successful drugs that are both economical and offer a long-lasting protection. The viral NS2B-NS3 serine protease (NS2B-NS3pro) is a promising target for the development of drug-like inhibitors, which are not available at the moment. In this study, we report retrocyclin-1 (RC-1) production in E. coli as a recombinant peptide to test against dengue NS2B-NS3pro.

Methods: Dengue NS2B-NS3pro was produced as a recombinant single chain protein in E. coli and purified by $\mathrm{Ni}^{+}$affinity chromatography. The RC-1 peptide was produced in E. coli and the tri-disulphide bonds were reformed in a diluted alkaline environment. Protease assay was performed using a fluorogenic peptide substrate and measured by fluorescence spectrometry. Real-time PCR was used for quantification of dengue serotype 2 (DENV-2) viral RNA produced in Vero cells.

Results: The RC-1 peptide inhibited the activity of recombinant NS2B-NS3pro with different values at 50\% inhibitory concentration $\left(I C_{50}\right)$ which are temperature dependent $\left(28^{\circ} \mathrm{C}, 46.1 \pm 1.7 \mu \mathrm{M} ; 37^{\circ} \mathrm{C}, 21.4 \pm 1.6 \mu \mathrm{M} ; 40^{\circ} \mathrm{C}\right.$, $14.1 \pm 1.2 \mu \mathrm{M})$. The presence of RC-1 significantly reduced viral replication in Vero cells infected with DENV-2 at simultaneous treatment after 48 hrs (70\%) and 75 hrs (85\%). Furthermore, moderate reduction in viral replication was observed at pre-treatment mode after 48 hrs (40\%) and 72 hrs (38\%) and post-treatment at 48 hrs (30\%) and 72 hrs (45\%).

Conclusion: Recombinant RC-1 inhibits DENV-2 replication in Vero cells by interfering with the activity of its serine protease. Thus, we propose that recombinant RC-1 is a potent, cost-effective dengue virus inhibitor. Therefore, it is suitable to consider RC-1 as a new candidate for drug development against dengue infection.
\end{abstract}

Keywords: Retrocyclin-1, Recombinant peptides, Dengue virus, NS2B-NS3 protease, Protease activity, Viral inhibition

\section{Background}

Dengue is an acute febrile viral disease with hundreds of millions of infections occurring each year and more than half of the world population are now at risk [1]. The virus uses host cell ribosomes to translate its genomic RNA to full length precursor polyprotein. Subsequently, proteolytic cleavage of the polyprotein results in formation of structural and non-structural proteins [2]. It

\footnotetext{
*Correspondence: rothan@um.edu.my

'Department of Molecular Medicine, Faculty of Medicine, University of Malaya, Kuala Lumpur 50603, Malaysia

Full list of author information is available at the end of the article
}

has been found that one of the most important nonstructural proteins is the NS3 protein. It has a trypsinlike serine protease domain (NS3pro) located within the $\mathrm{N}$-terminal 180 amino acid residues [3,4]. However, the activity of NS3pro depends on the interaction with its cofactor NS2B (47 amino acids) to form NS2B-NS3pro complex [5]. The importance of NS2B-NS3pro comes from its ability to cleave at various regions in the viral polyprotein [6-11]. It has been found that the disruption of NS2B-NS3pro function inhibits viral replication [12]. Therefore, the NS2B-NS3pro is considered as a potential target for antiviral drug design [13]. 
At present, there are neither vaccines nor other treatments available to prevent or cure this disease [14]. These facts emphasize the need for a better understanding of the mechanism of viral infection in order to combat this disease. Recently, computational studies indicated that disulphide cyclic peptides have potential to inhibit dengue NS2B-NS3pro $[15,16]$. In this study, our aim was to investigate the potential inhibition of retrocylin-1 (RC-1), a disulphide cyclic peptide, against dengue NS2B-NS3pro. It has been known that RC-1 (GICRCICGRGICRCICGR) is one of theta-defensins analogues which are circular, cationic, tri-disulphide bonded peptides with beta-sheet structure that can protect human peripheral blood lymphocytes from infection by HIV-1 strains [17]. This peptide is encoded in the human genome by a theta-defensins pseudogene [18]. However, it has only been found to play important roles in the innate host defense in the white blood cells of macaques, baboons and orang-utans $[19,20]$. Recent attempts have been made to confirm that human cells have the ability to produce correctly folded retrocyclins using aminoglycosides to read-through the premature termination codon found in the mRNA transcripts [21]. In our study, we successfully produced RC-1 in E. coli as a recombinant peptide. The soluble recombinant peptide was tagged with six histidine residues for metal column purification. To reform tri-disulphide bonds in the correct positions, the mis-folded peptide was refolded in alkaline and diluted environment. Recombinant RC-1 exhibited significant inhibitory potential against dengue NS2B-NS3pro and reduced viral replication in Vero cells. We propose that the recombinant $\mathrm{RC}-1$ could be considered as a candidate therapeutic peptide against dengue virus infection.

\section{Methods}

Mosquito cell lines $\mathrm{C} 6 / 36$ was expanded to $80 \%$ confluence and infected with DENV-2 viruses (Isolate D2MY0432618) and incubated at $32^{\circ} \mathrm{C}$ for 3 days. To amplify the cDNA fragment of NS2B-NS3pro sequence, DENV-2 infected cells were harvested and viral RNA was extracted using viral RNA Extraction Kit (Promega, USA) based on to the manufacturer's instructions. The cDNA fragment of NS2B-NS3pro was generated using the NS2BF (5'-ATA CTGAGGATCCGCCGATTTGGAACTG-3') and NS3R (5'-ATTGATCAAGCTTAAGCTTCAATTTTCT-3') which was then used as template to amplify NS2B (amino acids 49-95) and NS3pro (amino acids $1-180$ ) by PCR reactions.

\section{Construction of plasmids pQE30-NS2B (G4-T-G4) NS3pro}

To produce a single chain NS2B $\left(G_{4}-T-G_{4}\right) N S 3 p r o$, the $N S 2 B$ fragments were amplified separately by PCR using the primer pairs NS2BF and NS2BlikR (5'-ATACTGAG
GATCCGCCGATTTGGAACTG-3’, 5-ACCTACTAGG TACСТССТCСАCСCAGTGTCTGTTCTTC-3') while NS3pro was amplified using NS3likF and NS3R primers (5-ATCTATAGGTACCGGCGGTGGAGGTGCTGGAGTATTGTGG-3', 5'-AGCATAAGCTTAAGCTTCAATTT TCT-3'). The linker sequence and KpnI restriction sites were added to NS2BlikR and NS3likF primers. The PCR products were subsequently digested with $B a m H I$ and $K p n I$ And the purified fragments were cloned into pQE30 plasmid downstream of the $6 \mathrm{XHis}$ tag (all restriction sites are underlined).

\section{pET 303/CT His - RC-1}

The sense and antisense DNA fragments of 102 bases including the sequence of cleaved $\mathrm{XbaI}$ and $\mathrm{XhoI}$ restriction sites were chemically synthesized and hybridized. The double stranded DNA fragment was cloned directly into pET 303/CT His vector and transformed into $E$. coli.

\section{Protein production in $E$. coli}

The Escherichia coli XL1-Blue strain (Promega, USA) was transformed with pQE30-NS2B (G4-T-G4) NS3pro and $p E T-R C-1$. The recombinant $E$. coli was inoculated in Luria-Bertani liquid medium (1\% tryptone, 1\% $\mathrm{NaCl}, 0.5 \%$ yeast extract $\mathrm{w} / \mathrm{v}, \mathrm{pH} 7.0$ ) supplemented with $100 \mathrm{mg} / \mathrm{L}$ ampicillin and cultured overnight at $37^{\circ} \mathrm{C}$. In general, $10 \mathrm{ml}$ of overnight-grown culture was added to $1000 \mathrm{ml}$ of culture medium and incubated with shaking at $37^{\circ} \mathrm{C}$ until the optical density at $600 \mathrm{~nm}$ reached 0.5 . Isopropylthio- $\beta$-D-galactoside (IPTG) was then added to the culture medium at a final concentration of $0.5 \mathrm{mM}$ to induce protein expression and further incubation was applied for another $5 \mathrm{hrs}$ at $37^{\circ} \mathrm{C}$ in a shaking incubator. Bacterial cells were harvested by centrifugation at $4000 \mathrm{rpm}$ for $15 \mathrm{~min}$ at $4^{\circ} \mathrm{C}$.

\section{Protein purification}

The recombinant NS2B-NS3pro and RC-1 were produced as soluble proteins and purified using His GraviTrap $^{\text {TM }}$ Flow precharged Ni Sepharose ${ }^{\text {TM }} 6$ Fast column (Amersham Biosciences, USA) according to the manufacturer's instructions. In brief, the column was equilibrated with phosphate buffer $(20 \mathrm{mM}$ sodium phosphate buffer and $500 \mathrm{mM} \mathrm{NaCl}, \mathrm{pH}$ 7.4). The sample was loaded into the column and the column was washed with binding buffer (phosphate buffer containing $20 \mathrm{mM}$ imidazole, $\mathrm{pH}$ 7.4). The recombinant protein was eluted with elution buffer (phosphate buffer containing $200 \mathrm{mM}$ imidazole, $\mathrm{pH}$ 7.4).

\section{Refolding of recombinant RC-1}

The mis-folded recombinant $\mathrm{RC}-1$ was refolded as previously described [22]. In brief, urea was added to the 
purified $\mathrm{RC}-1$ to a final concentration of $2 \mathrm{M}$ and the $\mathrm{pH}$ was adjusted to 12.5 . Then, disulphide bonds were reduced by $5 \mathrm{mM}$ of $\beta$-mercaptoethanol and incubated at room temperature for $30 \mathrm{~min}$ with stirring. The denatured and reduced $\mathrm{RC}-1$ was diluted to a final concentration of $0.01 \mathrm{mg} / \mathrm{ml}$ with ice-cold refolding buffer (100 mM Tris-HCl, $1 \mathrm{mM}$ EDTA, 10\% glycerol, $250 \mathrm{mM}$ L-Arginine, $1 \mathrm{mM}$ reduced Glutathione and $0.5 \mathrm{mM}$ oxidized Glutathione ( $\mathrm{pH} 12.5)$ ). Protein sample was loaded into a dialysis tube and the dialysis was carried out overnight against 200 volumes of $100 \mathrm{mM}$ Tris- $\mathrm{HCl}, \mathrm{pH} 10$ to eliminate the residuals of urea and $\beta$-mercaptoethanol. Overnight incubation of peptide samples at $4^{\circ} \mathrm{C}$ was performed before the refolded $\mathrm{RC}-1$ was concentrated to $1 \mathrm{mg} / \mathrm{ml}$ by Vivaspin concentrating $50 \mathrm{ml}$ tubes with a 3,000 MW cut-off membrane (Sartorius, Germany). The $\mathrm{pH}$ was adjusted to 8.0 and the linker and 6XHis tag were eliminated after digestion with Factor $\mathrm{Xa}$ and passing the peptide through a Ni-affinity column.

\section{Antimicrobial activity of RC-1}

The disc diffusion susceptibility test was used to evaluate antimicrobial activity of the recombinant $\mathrm{RC}-1$. The samples of recombinant $\mathrm{RC}-1$ before and after refolding applications $(100 \mu \mathrm{g} / \mathrm{ml})$ were dropped onto a filter paper discs $(0.1 \mathrm{mg} / \mathrm{ml})$ and left to dry at room temperature. Then, the filters paper discs placed on an E. coli-inoculated Mueller-Hinton agar and a Saccharomyces cerevisiae inoculated yeast extract peptone dextrose (YPD) agar plates. Both E. coli and yeast inoculated plates were inoculated for $16 \mathrm{hrs}$ at $35^{\circ} \mathrm{C}$ and $30^{\circ} \mathrm{C}$, respectively.

\section{Protease assay}

The bioassay used in this study was published by Rothan and co-workers [23]. In brief, endpoint reaction mixtures with total volume of $200 \mu \mathrm{l}$ were prepared consisted of $20 \mu \mathrm{M}$ fluorogenic peptide substrate (Boc-Gly-Arg-ArgAMC), $2 \mu \mathrm{M}$ of recombinant NS2B-NS3pro, with or without $\mathrm{RC}-1$ of varying concentrations, buffered at $\mathrm{pH}$ 8.5 with $200 \mathrm{mM}$ Tris- $\mathrm{HCl}$. The $\mathrm{RC}-1$ was initially prepared in Tris- $\mathrm{HCl}$ buffer and assayed at five different concentrations, ranging from $9.3-150 \mu \mathrm{M}$. Three types of reactions which are buffer, buffer with enzyme and buffer with enzyme and different concentrations of RC1 were incubated at $28^{\circ} \mathrm{C}, 37^{\circ} \mathrm{C}$ and $40^{\circ} \mathrm{C}$ for 30 minutes. Subsequently, the substrate was added to each reaction mixture and incubated at same temperatures for another 30 minutes. Measurements were performed in triplicates using Tecan Infinite M200 Pro fluorescence spectrophotometer. Substrate cleavage was normalized against buffer only (control) and optimized at the emission at $440 \mathrm{~nm}$ upon excitation at $350 \mathrm{~nm}$. The readings were then used for calculating $K_{m}$ values of peptide substrate and $\mathrm{IC}_{50}$ values of peptide inhibitors using non-linear regression models in GraphPad Prism 5.0 software as previously described [24].

\section{Maximum non-toxic dose test (MNTD)}

Vero cells were seeded at $1 \times 10^{4}$ cells per well in triplicate in 96 well plates and propagated at optimal conditions $\left(37^{\circ} \mathrm{C}, 5 \% \mathrm{CO}_{2}\right.$ in humidified incubator). Recombinant RC-1 was diluted to serial concentrations $(37.5,75,100$, $125,150$ and $175 \mu \mathrm{M})$ with DMEM media supplemented with $2 \%$ FBS. Each dilution was tested in triplicate. Two control wells were included in each experiment: culture medium without $\mathrm{RC}-1$ and culture medium with different concentrations of the RC-1 in the absence of cells to subtract the background value of $\mathrm{RC}-1$ in the culture medium. The cell cultures were analyzed at 24, 48 and 72 hours using Non-Radioactive Cell Proliferation assay (Promega, USA) according to the manufacturer's instructions.

\section{Treatment of DENV-2 infected cells with recombinant RC-1}

Three independent experiments were carried out for pre, simultaneous and post-infection treatments with RC-1 at 24,48 and $72 \mathrm{hrs}$ of each infection in triplicates. Vero cells were grown in a 24 -well tissue culture plate $\left(1 \times 10^{5}\right.$ cells/ well), incubated $24 \mathrm{hrs}$ under optimal conditions and infected with DENV-2 (MOI of 2). For pre-treatment infection, $150 \mu \mathrm{M}$ of $\mathrm{RC}-1$ was added to the cells before virus inoculation and incubated for $24 \mathrm{hrs}$. Afterwards, DENV-2 supernatant was added, followed by incubation for $1 \mathrm{hr}$ with gentle shaking every $10 \mathrm{~min}$ for optimal virus to cells contact. The virus supernatant was removed, and the cells were washed twice with fresh serum-free DMEM media to remove residual virus. New complete DMEM media were added and the cultures were incubated for 24, 48 and 72 hrs at $37^{\circ} \mathrm{C}$, supplemented with $5 \% \mathrm{CO}_{2}$. Same applications were used for simultaneous treatment infection except the peptide was mixed with the virus supernatant and incubated at $37^{\circ} \mathrm{C}$ for $1 \mathrm{~h}$, and then inoculated onto Vero cells. The post-treatment infection was carried out after inoculation of Vero cells with DENV-2 and the complete DMEM medium was added containing the RC1. Then, the cultures were incubated for 24,48 and $72 \mathrm{hrs}$ at $37^{\circ} \mathrm{C}$ and $5 \% \mathrm{CO}_{2}$ with three wells of infected cells in each experiment were kept without $\mathrm{RC}-1$ as controls. Cellular supernatants were collected and stored at $-80^{\circ} \mathrm{C}$ for viral quantification using real time PCR.

\section{Dengue virus quantification by Real time PCR}

For quantification of copy number of DENV-2 RNA, the standard curve was generated by 10 -fold serial dilution of known copies of DENV-2 RNA. Viral RNA was extracted from culture supernatant using QIAmp viral RNA mini kit (Qiagen, Germany) according to the manufacturer's instructions. A fragment located at the 5'UTR 
region of the virus genome was used to generate the primers. One-step RT-PCR using SyBr Green Master Kit (Qiagen, Germany) was used to conduct absolute quantification using ABI7300 machine from Applied Biosystems (Foster City, CA). The PCR profile was 1 cycle of $50^{\circ} \mathrm{C}$ for $2 \mathrm{~min}, 1$ cycle of $95^{\circ} \mathrm{C}$ for $10 \mathrm{~min}, 40$ cycles of $10 \mathrm{sec}$ denaturation at $95^{\circ} \mathrm{C}, 20 \mathrm{sec}$ annealing at $57.7^{\circ} \mathrm{C}$ with a single fluorescence emission measurement and $30 \mathrm{sec}$ extension at $72^{\circ} \mathrm{C}$, followed by $5 \mathrm{~min}$ at $72^{\circ} \mathrm{C}$ for final extension. Dissociation curve analysis was added to the end of each run. Results were analyzed using the company's Sequence Detection Software Version 1.3.

\section{Statistical analysis}

All assays (Protease assay, Cytotoxicity assay, quantification of viral RNA by RT-qPCR) were done in triplicates. All statistical analyses were performed using GraphPad Prism version 5.01 (GraphPad Software, San Diego, CA). $P$ values $<0.05$ were considered significant. Error bars are expressed as \pm SD.

\section{Results}

Production of recombinant RC-1 and NS2B-NS3pro in

E. coli

Our aim was to produce $\mathrm{RC}-1$ in recombinant form in E. coli as a cost-effective expression system. In general, short peptides can be produced in a soluble form in $E$. coli. However, it is often challenging to have correct disulphide bond formation in cysteine rich peptides. We have produced $\mathrm{RC}-1$ as a soluble recombinant peptide fused with ten amino acids linker followed by a 6 XHis tag (Figure 1A). However, the product was biologically inactive due to the peptide mis-folding. The main challenge was to regenerate the activity of recombinant $\mathrm{RC}-1$ with correct refolding of the peptide by appropriate reformation of the three disulphide bonds (Cys3Cys16, Cys5-Cys14 and Cys7-Cys12). Thus, this required the reduction of all of mis-formed disulphide bonds by the action of $\beta$-mercaptoethanol before the refolding was carried out. Subsequently, the diluted basic environment was applied to allow the formation of intramolecules disulphide bonds and reduction in the formation of inter-molecules disulphide bonds. We used ten amino acids linker to avoid any interaction between the $6 \mathrm{XHis}$ tag and disulphide bonds. To test the activity of $\mathrm{RC}-1$ in inhibiting the NS2B-NS3pro, we produced NS2B-NS3pro in E. coli as a single-chain peptide. Nine amino acids linker was used to join NS2B with NS3pro downstream of the 6XHis tag sequence (Figure 1B). The recombinant proteins were detected by SDS-PAGE and purified using Ni-affinity column (Figure $1 \mathrm{C}$ and $\mathrm{D}$ ). To validate the functionality of the refolded $\mathrm{RC}-1$, we tested
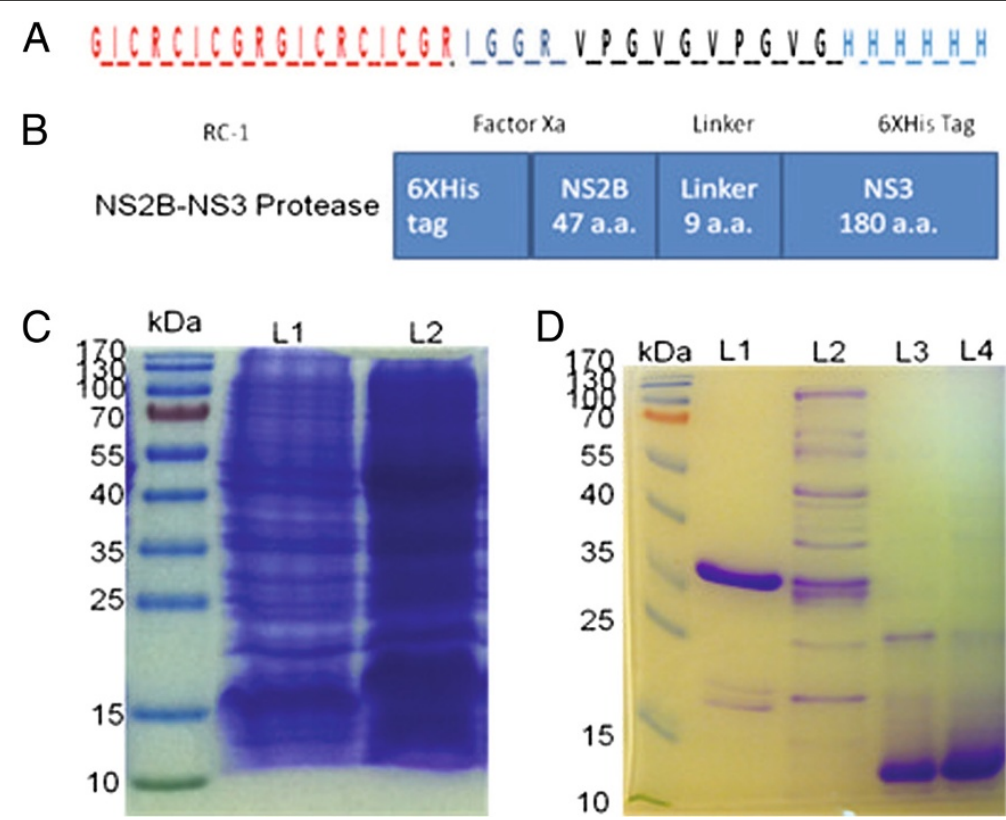

Figure 1 Production of recombinant RC-1 and dengue NS2B-NS3pro by E. coli. The sequence of RC-1 was linked by 10 amino acids to a 6XHis tag in pET 303/CT His vector. Factor Xa recognition sequence was inserted to cleave both the linker and 6XHis tag after purification. (A). The NS2B unit of dengue protease was linked to the NS3 by 9 amino acids and the entire DNA fragment was cloned into pQE30 vector downstream of a 6 XHis tag (B). The recombinant E. coli were cultured in Luria-Bertani liquid medium and induced with Isopropylthio- $\beta$-Dgalactoside (IPTG) to produce recombinant RC-1 (C, L1 before induction and L2 after induction) and the same procedure was applied to produce recombinant NS2B-NS3pro. The recombinant RC-1 and NS2B-NS3pro were purified by Ni-affinity column (D, L1 purified dengue protease, L2 NS2B-NS3pro before purification, L3 purified RC-1 and L4 purified RC-1 after refolding). 
A

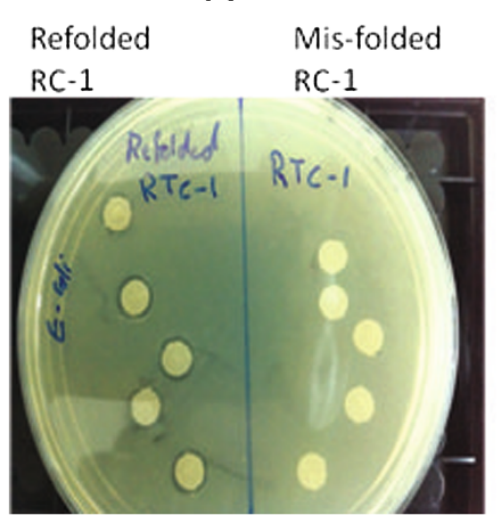

B

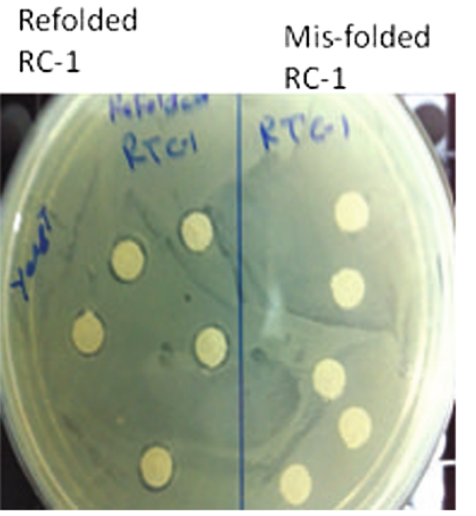

Figure 2 Antimicrobial activity of recombinant RC-1 after refolding. Each sample of RC-1 before and after refolding $(0.1 \mathrm{mg} / \mathrm{ml}) \mathrm{was}$ dropped on filter papers discs and left to dry at room temperature. The dry filter paper discs were placed on E. coli and yeast-inoculated antibiotic-free Mueller-Hinton-gar and YPD-agar plates respectively and incubated overnight at $37^{\circ} \mathrm{C}$ (E. coli) or $30^{\circ} \mathrm{C}$ (yeast). Recombinant RC-1 exhibited antimicrobial activity against $E$. coli $(\mathbf{A})$ and yeast (Saccharomyces cerevisiae) (B) compared to mis-folded form and control plates (column buffer) as exhibited by the presence of a clear circular zone in the agar plate.

for its antimicrobial activity against E. coli and yeast. It was found to exhibit antimicrobial activity compared to the inactive mis-folded form (Figure 2A and B).

\section{The inhibitory potential of RC-1 against Dengue protease} Dengue virus has the ability to propagate at different temperatures starting from mosquito temperature $\left(28^{\circ} \mathrm{C}\right)$, normal human temperature $\left(37^{\circ} \mathrm{C}\right)$ and at temperature of human with dengue fever $\left(40^{\circ} \mathrm{C}\right)$. Therefore, we carefully studied the activity of NS2B-NS3pro at $28^{\circ} \mathrm{C}, 37^{\circ} \mathrm{C}$ and $40^{\circ} \mathrm{C}$ in the presence or absence of recombinant $\mathrm{RC}-1$ peptide. The ability of NS2B-NS3pro to cleave the fluorogenic peptide substrate was variable at different temperatures. The highest activity was observed at $28^{\circ} \mathrm{C}$ and lowest activity was at $40^{\circ} \mathrm{C}$ while the activity at $37^{\circ} \mathrm{C}$ was in mid-range (Figure 3). The inhibition profile of $\mathrm{RC}-1$ was variable at different temperatures (Figure 4). The results showed that at $28^{\circ} \mathrm{C}, \mathrm{RC}-1$ exhibited $100 \%$ inhibition of NS2B-NS3pro activity at the concentration of $120 \mu \mathrm{M}$. Similarly, a complete inhibition was observed at $100 \mu \mathrm{M}$ and $37.5 \mu \mathrm{M}$ at $37^{\circ} \mathrm{C}$ and at $40^{\circ} \mathrm{C}$, respectively. The lowest $50 \%$ inhibitory concentration ( $\mathrm{IC}_{50}$ value) of RC- 1 was observed at $40^{\circ} \mathrm{C}(14.1 \pm 1.2 \mu \mathrm{M})$ and the highest $\mathrm{IC}_{50}$ at $28^{\circ} \mathrm{C}(46.1 \pm 1.7 \mu \mathrm{M})$ whilst at $37^{\circ} \mathrm{C}$, the $\mathrm{IC}_{50}$ of $\mathrm{RC}-1$ was $21.4 \pm 1.6 \mu \mathrm{M}$.

\section{The inhibitory potential of RC-1 against dengue virus replication in Vero cells}

The maximum non-toxic dose (MNTD) of RC-1 concentration in Vero cells was found to be $150 \mu \mathrm{M}$ for all of the three incubation periods, 24, 48 and $72 \mathrm{hrs}$ (Figure 5A). This concentration of RC-1 was used in pre, simultaneous and post-infection treatment modes in Vero cells infected with DENV-2 at 24, 48 and 72 hrs.
RNA of DENV-2 was extracted from RC-1 treated and control cells and quantified by real-time PCR. The results showed that the highest percentage of reduction in total viral RNA copies was observed at 24 hrs $(45.5 \% \pm 4.2)$, 48 hrs $(70 \% \pm 6.3)$ and 72 hrs $(85 \% \pm 7.1)$ for the simultaneous treatment mode compared to pre and post-treatment. Furthermore, there was a moderate reduction in viral replication at pre-treatments mode after $48 \mathrm{hrs}(40 \%)$ and

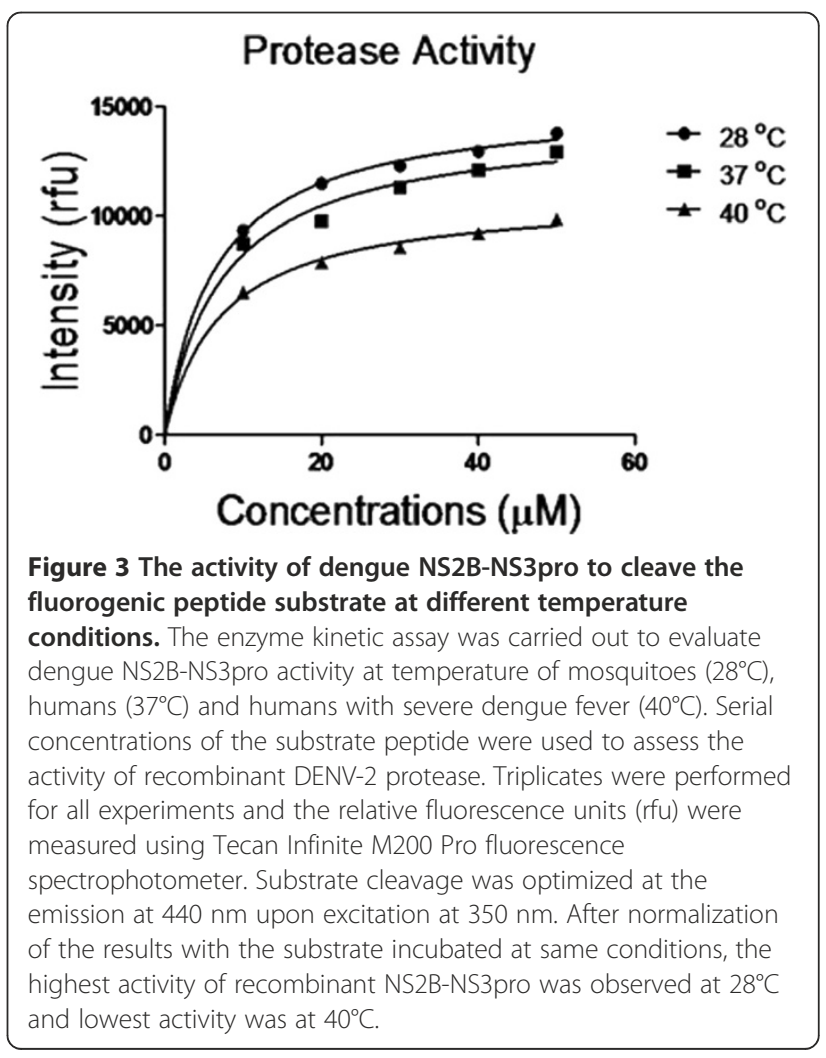


$28^{\circ} \mathrm{C}$
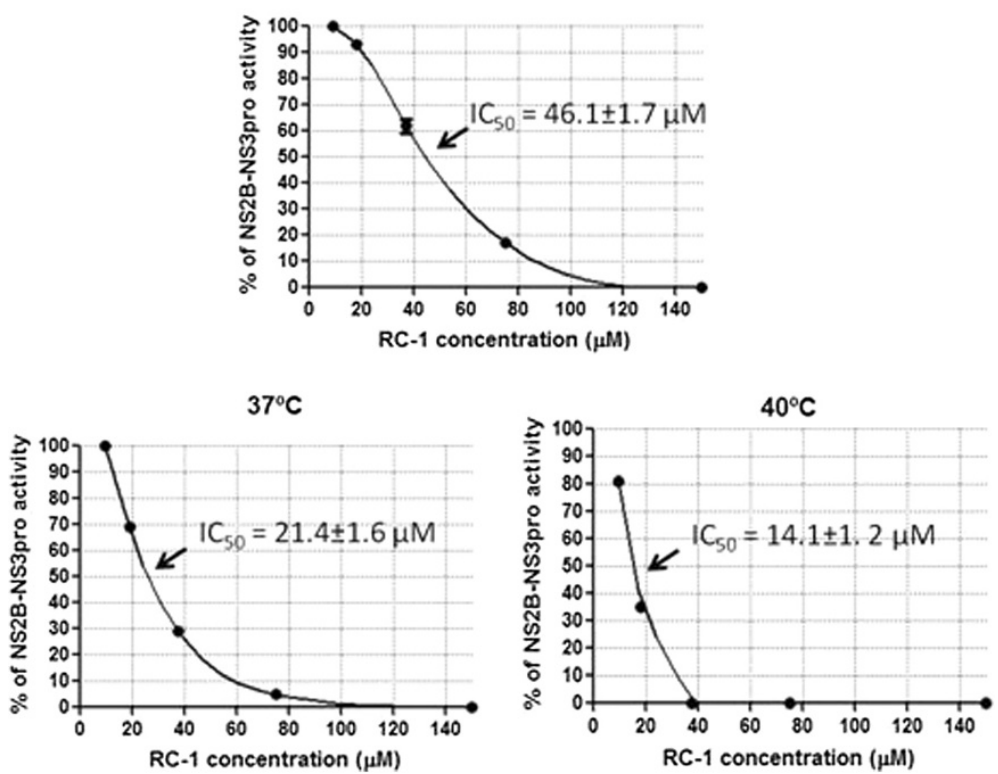

Figure 4 The inhibition potential of RC-1 against the activity of DENV-2 NS2B-NS3pro. End point protease inhibition assay was carried out to evaluate the inhibitory potential of RC-1 against the protease's ability to cleave a fluorogenic peptide substrate (Boc-Gly-Arg-Arg-AMC). The reaction mixtures consisted of $20 \mu \mathrm{M}$ substrate, $2 \mu \mathrm{M}$ of enzyme, with or without RC-1 of varying concentrations incubated at $28^{\circ} \mathrm{C}, 37^{\circ} \mathrm{C}$ or $40^{\circ} \mathrm{C}$ for 30 minutes. The results were normalized with the substrate alone and substrate with protease incubated at same temperatures. The inhibition was found to be temperature dependent with the highest concentration $(120 \mu \mathrm{M})$ at $28^{\circ} \mathrm{C}$ and the lowest concentration $(37.5 \mu \mathrm{M})$ at $40^{\circ} \mathrm{C}$.

$72 \mathrm{hrs}(38 \%)$ and post-treatment after $48 \mathrm{hrs}(30 \%)$ and 72 hrs (45\%) (Figure 5B).

\section{Discussion}

We conducted this study to evaluate the effect of RC-1, a cationic cyclic peptide on the activity of dengue protease as a target to inhibit replication of dengue virus. The RC-1 was produced inexpensively as a soluble recombinant peptide in $E$. coli and the tri-disulphide bonds were correctly reformed in alkaline and diluted environment. It has been found that the activity of cyclic $\mathrm{RC}-1$ is 3 -fold more potent than the open chain analogue, indicating the disulphide bonds have a crucial role in its stability and functionality [19]. Furthermore, this peptide is able to provide long-lasting protection against viral infection since its analogues do not exhibit pro-inflammatory reactions, haemolytic activity or cellular toxicity $[25,26]$. Thus, the recombinant $\mathrm{RC}-1$ peptide can be considered as a potential candidate for development of a successful drug to treat dengue and other infectious diseases.

The activity of recombinant NS2B-NS3pro was measured by a fluorescence-labelled substrate as previously described [23,27]. The function of dengue protease depends on the binding between NS2B and NS3pro to form NS2B-NS3pro complex. It has been found that this enzyme has an essential role in dengue virus replication through the cleavage of the viral polyprotein [12].
Therefore, blocking the active site or the interaction between the two subunits could directly disturb the activity of dengue protease and hence virus replication in host cells. Previous studies indicated that disulphide cyclic peptides have inhibition potential against dengue virus protease at different temperatures $[15,16]$. It has been known that the negatively-charged NS2B is positioned in a positive charged cleft on NS3pro [28]. Therefore it is possible that the $\mathrm{RC}-1$, which is a cationic peptide, may inhibit the activity of dengue protease via direct interactions with the active site or by blocking the binding between the two subunits of the protease complex. Further studies are necessitated to elucidate the interaction between $\mathrm{RC}-1$ and dengue protease that may have led to the inhibition of its activity.

Chemically synthesised $\mathrm{RC}-1$ and its analogues by solid-phase peptide synthesis have been commonly used in many studies to determine its inhibitory potential against viral replication such as HIV [29], avian influenza H5N1 virus [30], Herpes Simplex Virus [31] and other microorganisms such as Bacillus anthracis [32] and Staphylococcus aureus [25]. However, to the best of our knowledge, there are no studies reported on the production of the RC-1 peptide in recombinant form in E. coli. Nonetheless, retrocyclins expression has been reported in other expression systems such as plant [33] and mammalian cells [30]. Unlike E. coli, these expression systems cannot be scaled up for larger production of recombinant 

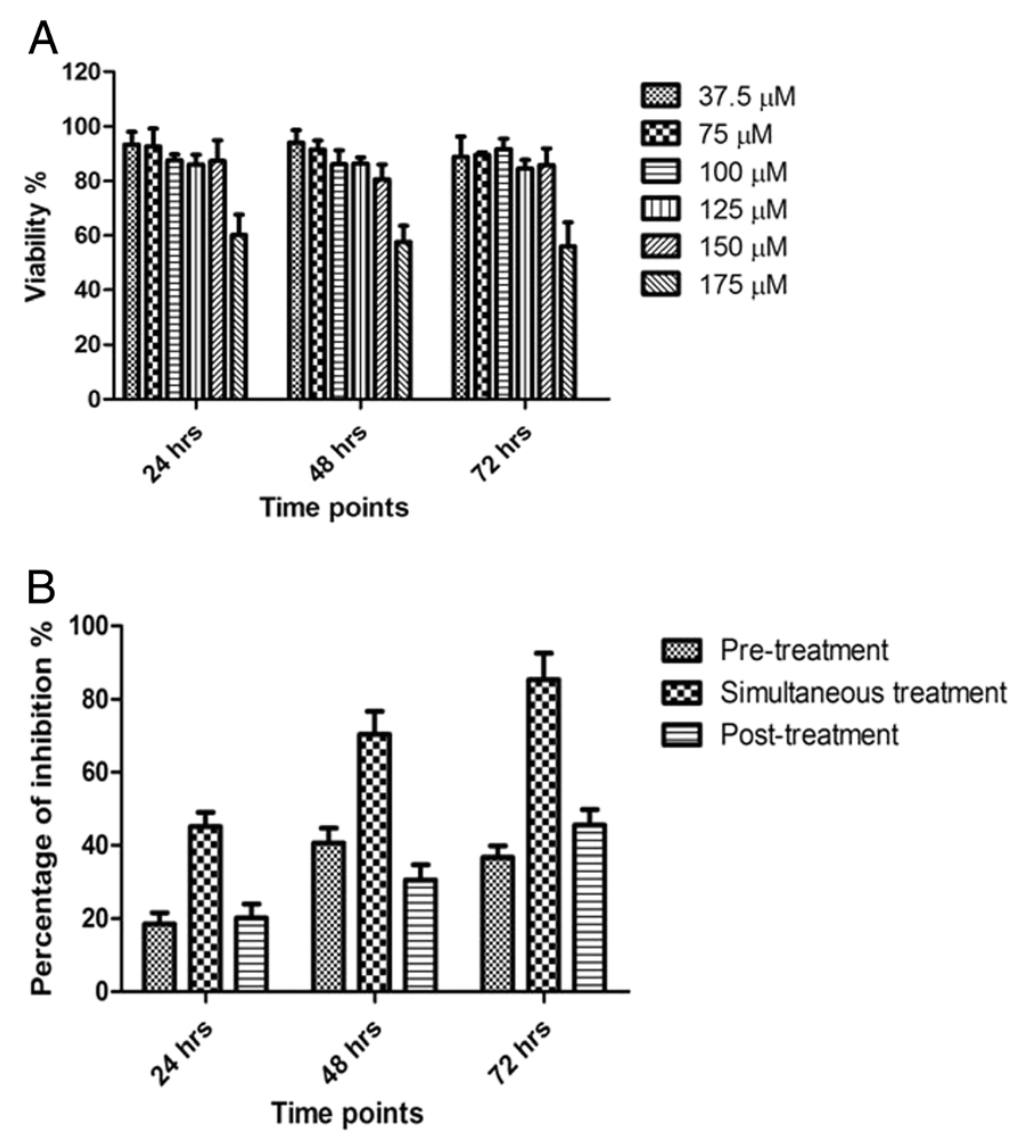

Figure 5 The percentage of viral reduction in Vero cells after different treatments with RC-1. (A) RC-1 was diluted to various concentrations $(37.5,75,100,125,150$ and $175 \mu \mathrm{M})$ with DMEM media supplemented with $2 \% \mathrm{FBS}$ and added to the cell culture. The viability of cells was analyzed at 24, 48 and 72 hrs using Non-Radioactive Cell Proliferation assay. (B) The cells were grown under the optimal conditions and infected with DENV-2 at the MOI of 2. The MNTD of RC-1 (150 $\mu \mathrm{M})$ was used to treat infected Vero cells and the results were normalized with infected cells without RC-1 as controls. Pre, simultaneous and post-infection treatments with RC-1 were applied at 24, 48 and 72 hrs of each infection. The percentage of inhibition was the highest for simultaneous treatment compared to pre and post-treatment. (Two way ANOVA was used with Bonferroni post-test, $\mathrm{P}<0.0001$ ).

protein in a cost-effective manner. We found that E. coli was able to produce soluble inactive recombinant RC-1 and the activity can be retrieved after refolding steps. The main challenge in maintaining the activity of recombinant $\mathrm{RC}-1$ was in the reformation of the inter-molecular tridisulphide bonds in its native order and to reduce intramolecular disulphide bonds, which were addressed in this study. We have reported that the optimal refolding of cysteine rich proteins can be achieved in an alkaline and diluted environment in the presence of redox agents, which is in agreement with other studies [22]. The intramolecular disulphide bonds were reduced after the dilution of the samples to $0.01 \mathrm{mg} / \mathrm{ml}$ in the presence of glycerol. In this study, the correct refolding was confirmed by the assessment of the RC-1 anti-microbial activity against E.coli and yeast (Saccharomyces cerevisiae).

Dengue protease exhibited highest activity at the temperature of mosquitoes $\left(28^{\circ} \mathrm{C}\right)$ compared to the temperature of humans $\left(37^{\circ} \mathrm{C}\right)$ and humans with severe dengue fever $\left(40^{\circ} \mathrm{C}\right)$. Overall, this suggests that despite the low copy number of virus that is delivered by a mosquito bite, the viral virulence is very high. The complete inhibition of dengue protease had been achieved by different concentrations of RC-1 depending on the temperatures as expressed by various $\mathrm{IC}_{50}$ values. These are crucial factors to be taken into consideration in developing the RC-1 as an inhibitor-like drug in order to understand the drug stability and dose requirements at different stages of infection. In this study, the inhibition potential of RC-1 is temperature dependent $\left(\mathrm{IC}_{50} 21.4 \mu \mathrm{M}\right.$ at $37^{\circ} \mathrm{C}$ and $14.1 \mu \mathrm{M}$ at $40^{\circ} \mathrm{C}$ ) which is important to develop the $\mathrm{RC}-1$ as an inhibitor-like drug to treat dengue. The inhibition potential of RC-1 is in the same range with other chemical compounds reported recently. These compounds inhibited recombinant dengue NS2B-NS3pro with $\mathrm{IC}_{50}$ of 15.4, 20.4 and $27.0 \mu \mathrm{M}$ [34].

It has been known that the compound toxicity could hinder the development of drugs against dengue virus. 
In this study, recombinant RC-1 exhibited low cellular toxicity in Vero cells $(150 \mu \mathrm{M})$ and has shown no noticeable cellular morphological abnormalities. In addition, it has been reported to have neither haemolytic activity nor cytotoxicity in different cell lines at up to a concentration of $500 \mu \mathrm{g} / \mathrm{ml}(250 \mu \mathrm{M})$ [26]. In addition, retrocyclins had no toxicity against human nasal epithelia at a concentration up to $200 \mu \mathrm{M}$, and did not induce any pro-inflammatory response in these cells [25]. In this study, the maximum non-toxic dose was used to treat the Vero cells infected with DENV-2. The viral replication was significantly declined after treatment with recombinant $\mathrm{RC}-1$ at pre, simultaneous and post infection treatment modes. The highest significant reduction in dengue virus RNA replication was observed after simultaneous treatment of infected Vero cells. Therefore, it is possible that the recombinant $\mathrm{RC}-1$ has an ability to reduce viral RNA replication by disturbing the activity of NS2B-NS3pro. Nevertheless, other possibilities of additional effects of $\mathrm{RC}-1$ on Vero cells that may lead to reduction in viral RNA should be also taken in consideration.

\section{Conclusion}

We successfully produced bioactive recombinant RC-1 in $E$. coli as a cost-effective expression system that can be developed for large-scale production. The recombinant RC-1 was able to inhibit dengue protease that led to reduction of dengue virus in Vero cells. These findings may have its importance in the development of therapeutic agent especially against dengue infection.

\section{Abbreviations}

RC-1: Retrocyclin-1; DENV-2: Dengue virus serotype 2; NS2B: NS2B cofactor amino acids sequence 49-95 in DENV-2 NS2B and 1394-1440 in DENV-2 polyprotein; NS3pro: NS3 protease amino acids sequence 1-185 in NS3 protease and 1476-1660 in DENV-2 polyprotein; NS2B-NS3pro: NS2B fused to NS3pro via 9 amino acids (G4-T-G4); AMC: Fluorogenic peptide substrate (Boc-Gly-Arg-Arg-AMC).

\section{Competing interests}

The authors declare that they have no competing interests.

\section{Authors' contributions}

HAR design performed the experiments and drafted the manuscript. $\mathrm{HCH}$ participated in the experiments and data analysis. TSR and SO participated in the analysis and preparation of the manuscript. NSR and RY participated in the design and drafted the manuscript. All authors approved the final manuscript.

\section{Acknowledgments}

This project was funded by the University of Malaya and Ministry of Science, Technology and Innovation (IPharm Grant 53-02-03-1049).

\section{Author details}

${ }^{1}$ Department of Molecular Medicine, Faculty of Medicine, University of Malaya, Kuala Lumpur 50603, Malaysia. ²Department of Pharmacy, Faculty of Medicine, University of Malaya, Kuala Lumpur 50603, Malaysia. ${ }^{3}$ Department of Chemistry, Faculty of Science, University of Malaya, Kuala Lumpur 50603, Malaysia.
Received: 22 April 2012 Accepted: 19 November 2012

Published: 21 November 2012

\section{References}

1. Anonymous: Division of vector-borne infectious disease. Dengue fever fact sheet, Centres for Disease Control \& Prevention; 2005. Available at: http://www.cdc.gov/ncidod/dvbid/dengues.

2. Stadler K, Allison SL, Schalich J, Heinz FX: Proteolytic activation of tickborne encephalitis virus by furin. J Virol 1997, 71:8475-8481.

3. Chambers TJ, Hahn CS, Galler R, Rice CM: Flavivirus genome organization, expression and replication. Annu Rev Microbiol 1990, 44:649-688.

4. Falgout $B$, Pethel $M$, Zhang YM, Lai CJ: Both non-structural proteins NS2B and NS3 are required for the proteolytic processing of dengue virus nonstructural proteins. J Virol 1991, 65:2467-2475.

5. Yusof R, Clum S, Wetzel M, Murthy HM, Padmanabhan R: Purified NS2B/ NS3 serine protease of dengue virus type 2 exhibits cofactor NS2B dependence for cleavage of substrates with dibasic amino acids in vitro. J Biol Chem 2000, 275:9963-9969.

6. Lin C, Amberg SM, Chambers TJ, Rice CM: Cleavage at the novel site in the NS4A region by the yellow fever virus NS2B-3proteinase is a prerequisite for processing at the downstream $4 A / 4 B$ signalase site. J Virol 1993, 67:2327-2335.

7. Arias CF, Preugschat F, Strauss JH: Dengue 2 virus NS2B and NS3 form a stable complex that can cleave NS3 within the helicase domain. Virology 1993, 193:888-899

8. Lobigs M: Flavivirus premembrane protein cleavage and spike heterodimer secretion require the function of the viral proteinase NS3. Proc Natl Acad Sci U S A 1993, 90:6218-6222.

9. Clum S, Ebner KE, Padmanabhan R: Cotranslational membrane insertion of the serine proteinase precursor NS2B-NS3 (Pro) of dengue virus type 2 is required for efficient in vitro processing and is mediated through the hydrophobic regions of NS2B. J Biol Chem 1997, 272:30715-30723.

10. Teo KF, Wright PJ: Internal proteolysis of the NS3 protein specified by dengue virus 2. J Gen Microbiol 1997, 78:337-341.

11. Stocks CE, Lobigs M: Signal peptidase cleavage at the flavivirus C-prM junction: dependence on the viral NS2B-3 protease for efficient processing requires determinants in $C$, the signal peptide, and prM. J Virol 1998, 72:2141-2149.

12. Geiss BJ, Stahla H, Hannah AM, Gari AM, Keenan SM: Focus on flaviviruses: current and future drug targets. Future. Med Chem 2009, 1:327-344.

13. Tomlinson SM, Malmstrom RD, Watowich SJ: New approaches to structurebased discovery of dengue protease inhibitors. Infect Disorders- Drug Targets 2009, 9:327-343.

14. Murrell S, Wu S, Butler M: Review of dengue virus and the development of a vaccine. Biotechnol Adv 2011, 29:239-247.

15. Tambunan US, Alamudi S: Designing cyclic peptide inhibitor of dengue virus NS3-NS2B protease by using molecular docking approach. Bioinformation 2010, 5:250-254

16. Tambunan US, Apriyanti N, Parikesit AA, Chua W, Wuryani K: Computational design of disulfide cyclic peptide as potential inhibitor of complex NS2BNS3 dengue virus Protease. African J Biotechnol. 2011, 10:12281-12290.

17. Daly NL, Chen YK, Rosengren KJ, Marx UC, Phillips ML, Waring AJ, Wang W, Lehrer RI, Craik DJ: Retrocyclin-2: structural analysis of a potent anti-HIV theta-defensin. Biochemistry 2007, 46:9920-9928.

18. Münk C, Wei G, Yang OO, Waring AJ, Wang W, Hong T, Lehrer RI, Landau NR, Cole AM: The theta-defensin, retrocyclin, inhibits HIV-1 entry. AIDS Res Hum Retroviruses 2003, 19:875-881.

19. Tang YQ, Yuan J, Osapay G, Ösapay K, Tran D, Miller CJ, Ouellette AJ, Selsted ME: A cyclic antimicrobial peptide produced in primate leukocytes by the ligation of two truncated a-Defensins. Science 1999, 286:498-502.

20. Penberthy WT, Chari S, Cole AL, Cole AM: Retrocyclins and their activity against HIV-1. Cell Mol Life Sci 2011, 68:2231-2242.

21. Venkataraman N, Cole AL, Ruchala P, Waring AJ, Lehrer RI: Reawakening Retrocyclins: Ancestral Human Defensins Active Against HIV-1. PLoS Biol 2009, 7:e1000095 doi:10.1371/journal.pbio.1000095.

22. Sijwali PS, Brinen $L$, Rosenthal PJ: Systematic optimization of expression and refolding of the Plasmodium falciparum cysteine protease falcipain2. Protein Expression Purif. 2001, 22:128-134.

23. Rothan HA, Abdulrahman AY, Sasikumer PG, Othman S, Abd Rahman N, Yusof R: Protegrin-1 Inhibits Dengue NS2B-NS3 Serine Protease and Viral 
Replication in MK2 Cells. J Biomed Biotechno/ 2012, ID 251482. doi:10.1155/ 2012/251482.

24. Cheng Y, Prusoff WH: Relationship between the inhibition constant (Ki) and the concentration of inhibitor which causes 50 per cent inhibition (IC50) of an enzymatic reaction. Biochemistry Pharmacol. 1973, 22:3099-3108.

25. Lamers RP, Eade CR, Waring AJ, Cole AL, Cole AM: Characterization of the Retrocyclin Analogue RC-101 as a Preventative of Staphylococcus aureus Nasal ColonizationAntimicrob. Antimicrob Agents Chemother 2011, 55:5338-5346.

26. Cole AM, Cole AL: Antimicrobial polypeptides are key Anti-HIV-1 effector molecules of cervicovaginal host defense. Am J Reproduction Immunol. 2008, 59:27-34.

27. Steuer C, Heinonen KH, Kattner L, Klein CD: Optimization of assayconditions for dengue virus protease: effect of various polyols and non-ionic detergents. J Bimolecular Screening 2009, 14:1102-1108.

28. Erbel P, Schiering N, D'Arcy A, Renatus M, Kroemer M, Lim S, Yin Z, Keller T, Vasudevan G, Hommel U: Structural basis for the activation of flaviviral NS3 proteases from dengue and West Nile virus. Nat Struct Mol Biol 2006, 13:372-373.

29. Owen SM, Rudolph DL, Wang W, Cole AM, Waring AJ, Lal RB, Lehrer RI: RC101, a retrocyclin-1 analogue with enhanced activity against primary HIV type 1 isolates. AlDS Res Hum Retroviruses 2004, 20:1157-1165.

30. Liang Q, Zhou K, He H: Retrocyclin 2: a new therapy against avian influenza H5N1 virus in vivo and vitro. Biotechnology Letter 2009, 32:387-392.

31. Yasin B, Wang W, Pang M, Cheshenko N, Hong T, Waring AJ, Herold BC, Wagar EA, Lehrer RI: $\theta$ defensins protect cells from infection by herpes simplex virus by inhibiting viral adhesion and entry. J Virology 2004, 78:5147-5156.

32. Wang W, Mulakala C, Ward SC, Jung G, Luong H, Pham D, Waring AJ, Kaznessis Y, Lu W, Bradley KA, Lehrer Rl: Retrocyclins kill bacilli and germinating spores of bacillus anthracis and inactivate anthrax lethal toxin. J Biol Chem 2006, 281:32755-32764

33. Lee $S B$, Li B, Jin $S$, Daniell H: Expression and characterization of antimicrobial peptides Retrocyclin-101 and Protegrin-1 in chloroplasts to control viral and bacterial infections Plant. Biotechnol J 2011, 9:100-115.

34. Yang CC, Hsieh YC, Lee SJ, Wu SH, Liao CL, Tsao CH, Chao YS, Chern JH, Wu $C P$, Yueh A: Novel dengue virus-specific NS2B/NS3 Protease Inhibitor, BP2109, discovered by a high-throughput screening assay. Antimicrob Agents Chemother 2011, 55:229-238.

doi:10.1186/1471-2334-12-314

Cite this article as: Rothan et al:: Inhibition of dengue NS2B-NS3

protease and viral replication in Vero cells by recombinant retrocyclin-1. BMC Infectious Diseases 2012 12:314.

\section{Submit your next manuscript to BioMed Central and take full advantage of:}

- Convenient online submission

- Thorough peer review

- No space constraints or color figure charges

- Immediate publication on acceptance

- Inclusion in PubMed, CAS, Scopus and Google Scholar

- Research which is freely available for redistribution

Submit your manuscript at www.biomedcentral.com/submit
Biomed Central 